Gunawardana and Somaratne. 2000. Sri Lankan Journal of Agricultural Economics. Volume 3, Number 1.Pp 15 - 45.

\title{
Non-Plantation Agricultural Economy of Sri Lanka: Trends, Issues and Prospects"
}

\author{
P.J. Gunawardana ${ }^{* *}$ and W.G. Somaratne $\mathrm{e}^{* * *}$
}

\begin{abstract}
The non-plantation agricultural economy of Sri Lanka has undergone a noticeable transition from 1978, compared to the period 1970-77, mainly due to economic reforms implemented in the country from 1978. This paper aims to: describe the major policies towards non-plantation agriculture from 1970 to date; analyse the diversification and commercialisation of non-plantation agriculture by examining the trends in prices of commercial food crops vis-à-vis subsistence food crops, and the trends in area, production and yield of commercial food crops and agro-industrial crops vis-à-vis subsistence food crops; examine the outward orientation of non-plantation agriculture by analysing trends in imports and exports; and investigate the current issues and future prospects for non-plantation agriculture.
\end{abstract}

\section{Introduction}

The non-plantation agricultural sector in Sri Lanka is concerned with the production and marketing of food crops such as cereals, pulses, coarse grains, roots and tubers, chillies, onions, vegetables, fruits, and sugar, mainly for domestic consumption.
This sector contributed about 11 per cent of GDP in 1997 (Central Bank of Sri Lanka, 1997a). About 25 per cent of the employed labour force are in the non-plantation agricultural sector (Central Bank of Sri Lanka, 1995a). Paddy (rice) and other food crops grown in the non-plantation sector account for about 58 per cent of total

* The earlier version of this paper was presented to the $7^{\text {th }}$ International Conference on Sri Lanka Studies, 3-6 December 1999, Canberra, ACT, Australia.

** Senior Lecturer, Department of Agricultural Economics, Victoria University of Technology, Footscray Park Campus, Melbourne, Australia.

*** Senior Research and Training Officer, Agricultural Resource Management Division, Hector Kobbekaduwa Agrarian Research Training Institute. 
cultivable land, while the plantation sector and other crops account for 38 per cent and 4 per cent, respectively (World Bank, 1990). Non-plantation agriculture is the major economic activity that provides livelihood for over 60 per cent of population of Sri Lanka.

The non-plantation agricultural economy has undergone a noticeable transition from 1978, compared to the period 1970-77, mainly due to economic reforms implemented in the country from 1978. During 19701977, there was a heavy emphasis on import-substitution under a protectionist framework and profound government intervention in both domestic and external economic affairs. From 1978 to date, governments have implemented farreaching economic reforms under an open economic framework. The reform 'package' included the reduction of protection provided to import competing sectors, exchange rate adjustments, fiscal and monetary reforms, liberalisation of domestic factor and product markets, and privatisation of some government business enterprises (Athukorala and Jayasuriya, 1994; Bandara and Gunawardana, 1989; Cuthbertson and Athukorala, 1991; Lakshman, 1994; Rajapathirana, 1988).

Previous studies that examined various aspects of transition of non- plantation agriculture under different economic regimes during 1970-97 include Bhalla (1991), Dunham (1992; 1993), Edwards (1993), and Gunawardana and Somaratne (1999). Bhalla (1991) deals with the political economy and determination of foodcrop prices. Dunham (1992) examines productivity and commercialisation of non-plantation agriculture. Dunham (1993) deals with crop diversification and exports from non-plantation sector. Edwards (1993) examines the protection provided to food crops from import competition. Gunawardana and Somaratne (1999) analyse the impact of different economic regimes on economic performance of non-plantation agriculture during 1970-97.

The aims of this paper are: (i) to describe the major policies towards non-plantation agriculture from 1970 to date; (ii) to analyse the diversification and commercialisation of non-plantation agriculture by examining the trends in prices of commercial food crops vis-à-vis subsistence food crops, and the trends in area, production and yield of commercial food crops and agroindustrial crops vis-à-vis subsistence crops; (iii) to examine the outward orientation of non-plantation agriculture by analysing trends in imports and exports; and (iv) to investigate the current issues and future prospects for non-plantation 
agriculture. For the purpose of this paper the crops produced in the nonplantation agriculture are categorised as: (i) subsistence food crops [paddy/rice, manioc (cassava), sweet potatoes, kurakkan (finger millet)], (ii) commercial food crops (cowpea, green gram, onions, potatoes, chillies, vegetables and fruits), and (iii) agroindustrial crops (maize and sugar).

The remainder of the paper is organised as follows: The major policies towards non-plantation agriculture from 1970 to date are described in section two. The trends in the extent of diversification and commercialisation of non-plantation agriculture are analysed in section three. The trends in the degree of outward orientation of non-plantation agriculture are examined in section four. Current issues and prospects for non-plantation agriculture are outlined in section five. Concluding remarks are included in section six.

\section{Major Policies towards Non- Plantation Agriculture}

Major policies towards nonplantation agriculture from 1970 to date are discussed in this section within the general economic policies that prevailed during different political regimes; 1970-77, 1978-88, 1989-93 and 1994 to date.

\section{The Period 1970-77}

The Sri Lankan economy was faced with external shocks of world oil crises, and world food and fertiliser shortages during this period. These shocks and foreign exchange limitations forced the then SLFP-led coalition government to impose restrictions on imports of food and agricultural inputs such as fertiliser, tractors and agro-chemicals. Foreign exchange controls and quantitative restrictions (QRs) on imports under import licensing were also imposed. Many private business enterprises were taken under government control and management. Several new, stateowned industrial enterprises were established. The government increased its share in export-import trade. However, the government encouraged export promotion, especially of nontraditional exports and foreign direct investment in the mainly import competing industries. The government used the dual exchange rate system (introduced in 1968 by the previous government) to promote nontraditional exports and to curtail imports. Thus, non-traditional exports were invoiced at the higher (Foreign Exchange Entitlement Certificates or FEECs) exchange rate, while other exports and all imports were invoiced at the lower official exchange rate. 
The government adopted a policy of food self-sufficiency under increased government intervention in domestic factor and product markets. Sometimes, restrictions were imposed on internal transportation and distribution of food, which led to the emergence of parallel (black) markets. Large tracts of land cultivated with tea, rubber, coconut and paddy were nationalised under an ambitious land reform program. ${ }^{1}$

Despite limited availability of imported inputs, in order to increase domestic food output, during 1970-77 the government continued to supply subsidised material inputs such as fertiliser, pesticides, tractors, improved seed and planting material. It also carried out irrigation development and land settlement programmes in the Dry Zone; a comprehensive network of research and extension services; subsidised institutional credit; crop insurance, marketing and agrarian service institutions; and guaranteed minimum prices for paddy and subsidiary food crops. ${ }^{2}$

A major marketing institution for paddy and subsidiary food crops, the Paddy Marketing Board (PMB) was established in 1971. The PMB was made the sole purchaser of paddy from farmers during 1973-75 when private trade and transport of paddy and rice were made illegal. While pursuing a policy of increasing domestic output of paddy and subsidiary food crops, the government also continued to provide rice to consumers at subsidised prices which was in operation since the early 1940s. Subsidised rice was provided to all persons above one year of age, under a non-targeted rationing scheme from the early 1950s until 1978. During 1970-77, income tax payers paid higher (market) prices for rationed rice, than those who did not have to pay income taxes. Government purchases of rice under the Guaranteed Prices Scheme and imports were the sources of supply for the rice-rationing scheme ${ }^{3}$.

1. Details are provided in Gunawardana (1981a).

2. In large part, these policies and programs were a continuation of those implemented by the UNPled coalition government that wielded power during 1965-70. For greater details of these policies see, Edirisinghe and Poleman (1976), Richards and Gooneratne (1980), Sirisena (1986), Thorbecke and Svejnar (1987), and Wickremeratne (1977).

3. Details of the Guaranteed Price Scheme and public food distribution schemes are given in Edirisinghe (1987), Edirisinghe and Poleman (1976). Gavan and Chandrasekera (1979), Gunawardana (1987; 1997), Gunawardana and Quilkey (1987; 1993), and Richards and Gooneratne (1980). 
The contribution of non-plantation agriculture to GDP of Sri Lanka was 17.5 per cent during 1970-77. About 29 per cent of the total employed work force were in non-plantation agriculture in 1971. The annual average growth rate of non-plantation agriculture was 3.5 per cent during 1970-77. This growth rate was similar for the services sector, but higher than for all other sectors. However, plantation agriculture recorded a negative growth rate during this period (Gunawardana and Somaratne, 1999).

\section{The Period 1978-89}

During this period the UNP government implemented a wide range of economic reforms in order to accelerate economic growth, create employment opportunities, increase capacity utilisation, stimulate savings and investment, improve the balance of payments and achieve international competitiveness (Athukorala and Jayasuriya, 1994; Rajapathirana, 1988). To accomplish these objectives, the exchange rate was unified and allowed to be marketdetermined. Exchange controls were removed. The Rupee was devalued substantially. Massive public sector investment programs were initiated (the main projects being the Mahaweli irrigation, power and settlement project, housing development projects, and 'Integrated Rural Development Projects-IRDP). A Free Trade Zone was established to attract foreign investments (mainly in garment manufacturing). An Export Development Board was established to provide direct support for export oriented sectors. Trade liberalisation was a major component of the policy reform package. Most quantitative restrictions (QRs) on imports were replaced with a six-band duty system ranging from zero (0) per cent for 'essential' consumer good imports to 500 per cent for imports of 'luxury' items. The tariff structure was periodically reviewed since 1980 , and changes were made according to recommendations of the Presidential Tariff Commissions appointed in 1980 and 1985.

During 1978-83 (the initial six years of economic policy reforms), the policy objectives for the nonplantation agricultural sector were not clearly specified. However, during this period, a policy of import liberalisation was followed, under which the non-plantation agriculture was exposed to import competition, particularly in relation to crops such as potatoes, onions and chillies. During 1970-77, these crops were produced in the country under heavy protection. For the paddy/rice sector, selfsufficiency seems to have been the goal. In 1984, policy goals were specified as that of achieving selfsufficiency in some importable commodities, namely rice, sugar and 
pulses, while increasing domestic output whenever possible of other importables such as chillies, onions and potatoes (National Planning Division, 1984). However, in order to 'safeguard consumer interests', imports of these commodities were allowed when their prices in domestic markets increased sharply due to bad harvests, speculation, or other disturbances. Diversification of the crop mix away from subsistence crop towards commercial, agro-industrial and exportable crops (mainly vegetables and fruit and cut flower) was also on the policy agenda.

The introduction of the 'open economic policy' in 1977 has also led to the elimination of most of the controls, which operated in domestic factor and product markets under the previous government. Major fiscal policy reforms included the replacement of generic (non-targeted) food subsidies with a targeted Food Stamp Scheme in 1978, and the reduction of fertiliser subsidies. Reforms in the financial sector including financial deregulation, which allowed the operation of the private sector in banking and finance, while easing the availability of credit, pushed up interest rates (Lakshman, 1994). Government concessions on agricultural credit were reduced. However, credit was provided under special credit schemes, designed within several Integrated Rural Development Projects. ${ }^{4}$

In order to increase the output of food crops produced in the nonplantation agricultural sector, the guaranteed ('floor') prices for rice and subsidiary food crops were increased. The government continued with the provision of research (although research spending has been reduced; see later), extension services and irrigation, while removing the controls on the importation of agricultural inputs and machinery. The purchase of paddy from farmers under the minimum purchase price scheme (strangely called "floor price scheme") declined sharply (from 36 per cent of domestic output in 1978 to below 5 per cent by 1989). This was a result of the deregulation of, and increased private sector participation in, the marketing of rice and the abolition of the non-targeted rice- rationing scheme. The role of the PMB has been reduced to "the buyer of last resort', supporting the "floor prices" when market prices fall below the "floor prices", particularly during harvests (Gunawardana and Quilkey, 1993).

4. See, for example, Gunawardana (1981b; 1983). 
The government also introduced a bonded warehousing system for rice in the mid 1980s. Under this system the registered private importers of rice were allowed to import rice at the world market price and pay the tariff rate of 35 per cent on c.i.f price The bondsmen were allowed to release stocks of rice from warehouses to the market during lean seasons of domestic production. This was to ease the upward pressure on prices and thereby provide price stability, especially to protect consumer interests.

The structural change due to economic reforms during the first six years (1978-83) saw the contribution of non-plantation agriculture to GDP falling to about 12 per cent. By 1981, its contribution to employment also fell to 27 per cent. During 1978-93, non-plantation agriculture grew at an annual average rate of 5.3 per cent in common with all sectors of the economy. However, the growth rate of the non-plantation sector was the lowest of all sectors. The contribution of non-plantation agriculture to GDP increased to 14 per cent during 198489 . The annual average growth rate of the non-plantation sector dropped to a low of 0.6 per cent during this period. This growth rate was the lowest of all sectors. During the same period all sectors except the plantation sector experienced lower growth rates than during 1978-89 mainly due to escalation of ethnic violence, civil wars and insurgencies (Gunawardana and Somaratne, 1999).

\section{The Period 1989-93}

Macroeconomic instability,
compounded by government mismanagement of the domestic economy, mounting ethnic violence and insurgency, put a halt to the initial wave of liberalization during 1978-88

(Dunham and Kelagama, 1994; Rahjapathirana, 1988). The massive donor-funded public investment projects during the early 1980s and escalating of civil wars produced mounting budget deficits, inflationary pressures, erosion of export incentives, current account deficits and external debts. The first wave of reforms and liberalisation measures caused hardship to certain sections of the community. Some, but not all, received compensation in the form of investment opportunities or jobs under a changed leadership. The UNP government implemented a second wave of economic liberalisation and policy reforms from 1989.

5. Details of macroeconomic instability and relevant data can be found in Athukorala and Jayasuriya (1994, pp.45-55 and 77-93). 
Under the second wave of liberalisation, the maximum nominal tariff on imports was reduced to 45 per cent by 1993 . The tariff system was altered from a six band structure in 1988 to a three band structure in 1992 to further relax the rigidity and distortions in non-plantation agriculture and manufacturing sectors (Presidential Tariff Commission on Tariff and Trade, 1994). The Rupee was devalued in order to promote exports.

Three 'high profile projects' were also implemented: (i) privatisation of a further number of public enterprises; (ii) new emphasis on export oriented industrialisation under a more liberalised trade regime and further incentives to foreign investors in Export Processing Zones; and (iii) a major programme for the alleviation of poverty (Dunham and Kelagama, 1994). Under the poverty alleviation programme, a direct income transfer scheme (Janasaviya) was designed, for 50 per cent of the population ('poor'), over a two-year period during which the recipients were expected to develop necessary skills for self-employment. In 1989 the cash value of food stamps was doubled, and the food stamp scheme was better targeted to cover only the families entitled to assistance under the Janasaviya scheme.
During 1989-93, there were reductions in investments on new irrigation and land settlement projects. Under the loan agreements signed with the World Bank and IMF, the subsidy on fertiliser was totally removed with effect from 1 January 1990. The private sector was allowed to carry out fertiliser marketing activities, alongside with government agencies. Fertiliser prices were aligned with world market prices. Interest rates on rural credit schemes were increased. Crop diversification and promotion of exports of nonplantation agriculture were encouraged further.

The contribution of non-plantation agriculture to GDP was maintained at 14 per cent during 1990-93, but its contribution to employment fell to about 25 per cent in 1991 . The annual average growth rate of non-plantation agriculture was 0.9 per cent during 1990-93, which is the lowest growth rate among all sectors except the plantation sector, which recorded a negative growth rate. All other sectors of the economy registered higher and increasing growth rates during 199093 (Gunawardana and Somaratne, 1999).

\section{The Period 1994 to Date}

The newly elected United Front government in 1994 continued with the liberalised economic policies 
implemented by the previous regimes during 1978-93. However, the new government emphasised a balanced approach to economic growth and poverty alleviation. The present government sets out its agricultural policy directions as follows: "The agricultural development strategy of the government of Sri Lanka will aim at removing institutional and policy obstacles, which have retarded profitability and constrained investment in this sector"6.

The almost immediate changes in agricultural policies affected by the new government included: tariff reduction on the imports of rice, subsidiary food and agricultural inputs (especially for tractors); reinstating of the fertiliser subsidy; lowering interest rates on agricultural credit; and reducing turnover tax on agricultural inputs ${ }^{7}$. Further, consumer subsidies on wheat flour and bread have also been partially removed in order to correct the distortions on the consumption side between wheat and rice and avoid the heavy burden on government expenditure.

Under the new fertiliser subsidy scheme introduced in 1994, Rs. 500 per acre was granted to farmers in the non-plantation sector as a fertiliser subsidy. Subsequently, the scheme was changed and the importers were paid a portion of the subsidy, which was based on all varieties of fertiliser. The equivalent c.i.f. price of fertiliser was fixed at Rs. 6100 per metric ton and if the c.i.f. price was above this, the importers were paid the difference by the government. To maintain the fertiliser subsidy scheme, the government allocated Rs. 1500 million per year as budgetary provisions. At present the subsidy is provided only on Urea fertiliser, and the plantation sectors are not allowed to get provisions under this fertiliser subsidy scheme.

In compliance with GATT/Uruguay Round Agreement on Agriculture (GURAA), Sri Lanka has bound all tariffs on imports of agricultural products at a uniform rate of 50 per cent (World Trade Organisation, 1995). Among these were approximately 700 agricultural products, including cereals, sugar, maize, spices, oils, fruit, vegetables, fruit juices and other fruit preparations, milk, milk powder, and meat. Since Sri Lanka had not previously bound its agricultural tariff under the GATT, there is no

6. Policy statement of the government of Sri Lanka, presented by the, President of Sri Lanka, 9th February, 1996.

7. Details of the policies can be found in Centre for International Economics (1995) and Central Bank of Sri Lanka (1995b). 
obligation to reduce tariffs from the bound level (50 per cent) during the 10 -year phase-in period. In fact, Sri Lanka's gazette tariff rates on all agricultural products are below the bound rate (Presidential Commission on Tariffs and Trade, 1994).

At the end of 1995 the government dismantled the bonded warehousing system for rice and allowed completely duty free imports of rice as a temporary measure to curb the price escalations in the domestic market. This depressed prices received by domestic producers to a great extent so that in 1999 the government has re-imposed the 35 per cent tariff rate for rice imports.

In line with the recommendation of the National Development Council (NDC) the government in August 1999 reintroduced the minimum purchase price scheme (strangely called "floor price scheme") for ten of the non-plantation crops which include rice, potatoes, dried chillies, onions, cowpea, green gram, maize and ground nuts. The sole implementing agency for this scheme is the Co-operative Wholesale Establishment (CWE). The "floor prices" are fixed on par with the world market prices (border prices) "to safeguard the farmers' interests".

A Cabinet Sub-Committee on Agricultural Marketing (CSAM) was established in mid 1999. The main objectives of the CSAM are: (i) to review the situation of food supply, stock positions, levels of imports, international market prices and domestic prices, and (ii) to make recommendations to the Cabinet on short term policy options in relation to improving agricultural marketing and stabilising the prices food crops.

All operations of the Paddy Marketing Board (PMB), including purchasing of paddy at the farm gate, paddy milling and distribution of rice through its retail outlets and cooperative societies have been dismantled since September 1999. Private sector dealers are allowed to operate on a competitive basis in purchasing paddy from farmers, paddy milling and distribution of rice. However, state intervention in the paddy/rice market is still maintained via the CWE, which is involved in the functions of purchasing, milling and distribution of rice through retail outlets of the CWE, and appointed private sector franchise agents.

At the end of 1997, the government introduced an incentive scheme for export-oriented agro-based industries in the rural sector under the Bureau of Investment. The purpose of this scheme is to encourage technological advancement in agrobased industries in the rural sector via private sector companies as joint 
ventures with farmer companies or as direct investments. The incentive provisions include duty free imports of seeds, planting material, required technology, and machinery (for example, refrigerated trucks for transportation of perishable products for export). The rate of concessions will increase depending on the number of people employed in the enterprise.

Non-plantation agriculture's share in the GDP fell to 12 per cent during 1994-97. Its annual average growth rate during this period was -0.3 per cent, showing a significant deterioration in non-plantation crop performance. Plantation agriculture grew at a rate of 2.2 per cent, the highest rate since 1970-77. All other sectors $^{8}$ of the economy recorded slightly lower but still impressive growth rates during 1994-97 compared to 1990-93 (Gunawardana and Somaratne, 1999).

\section{Diversification and}

\section{Commercialisation of Non- Plantation Agriculture ${ }^{9}$}

In this section, diversification and commercialisation of non-plantation agriculture, particularly during 197997, are examined by analysing the trends in prices of commercial food crops relative to those of subsistence food crops, and area, production, and yield of commercial food crops and agro-industrial crops relative to those of subsistence food crops.

\section{Prices of Commercial Food Crops Relative to the Prices of Subsistence Food Crops}

One of the policy objectives for non-plantation agriculture during 1979-97 was to diversify the crop mix away from traditional, subsistence crops towards commercial (cash) crops. This was thought to be necessary, as the country was close to achieving self-sufficiency in paddy (rice), and excess production of rice could depress farm incomes in the absence of export market opportunities. To achieve the diversification objective, the output price ratio must be favourable for commercial crops and against subsistence crops, and the favourable ratio must increase or at least remain constant over time.

Therefore, in this section we examine the trends in the ratio of the weighted average real price of five commercial food crops (potatoes, cowpea, green gram, red onions and chillies) to the real price of paddy (the

\footnotetext{
8. All other sectors include construction, manufacturing and services sectors.

9. Data used to derive the index numbers in Tables 1 to 4 are not included in this paper because of space limitations. The data are available on request from the senior author.
} 
major subsidence food crop) for which consistent price data series are available.

The data are included in table 1 . The price ratios indicate that relative prices were in favour of commercial food crops compared to paddy during 1970-77 as well as during 1978-97. However, during much of the period 1978-93, the price ratio shows a general downward trend (except during 1984-86). This suggests that in general, during 1978-93, real prices of commercial food crops did not increase faster than the real prices of subsistence food crops. During 199497, it appears that real prices of commercial food crops have declined much slower than real prices of subsistence food crops.

\section{Land Areas, Production, and Yields of Commercial Food Crops and Agro-industrial Crops Relative to those of Subsistence Food Crops ${ }^{10}$}

Following liberalisation and marketing reforms within nonplantation agriculture, production is expected to shift in favour of commercial products vis-a-vis subsistence products. The extent to which the expected diversification and commercialisation has occurred within the non-plantation agricultural sector is examined below. The five commercial food crops considered in this section are potatoes, cowpea, green gram, red onions and chillies. The subsistence food crops are paddy, manioc and kurakkan, and the agroindustrial crops are maize and sugar.

The indicators used in this section are: (i) the ratio of average area indices between commercial food crops and subsistence food crops (Table 2), (ii) the ratio of average area indices between agro-industrial crops and subsistence food crops (Table 2), (iii) the ratio of average production indices between commercial food crops and subsistence food crops (Table 3), (iv) the ratio of average production indices between agroindustrial crops and subsistence food crops (Table 3), (v) the ratio of average yield indices between commercial food crops and subsistence food crops (Table 4), and (vi) the ratio of average yield indices

10. Some caveats should be made regarding data used in this section. In Sri Lanka, as in many developing countries, data on area, production, and prices of food crops are subject to errors with respect to measurement and recording. Thus, data should be regarded as indicating only the 'broad orders of magnitudes'. Furthermore, data gathering in some districts of the country were severely disrupted due to ethnic violence and civil war in the north and east (1983 to date) and insurgencies (whole country, 1971; south, 1987-89). 
Table 1: $\quad$ Ratio of real producer prices of commercial food crops to real producer price of paddy, 1970-97

\begin{tabular}{|c|c|c|c|}
\hline Year & PPDI & PCCI & RP5CCP \\
\hline 1970 & 100.0 & 100.0 & 1.00 \\
\hline 1971 & 97.2 & 115.9 & 1.19 \\
\hline 1972 & 98.2 & 227.8 & 2.32 \\
\hline 1973 & 92.1 & 195.5 & 2.12 \\
\hline 1974 & 112.8 & 169.5 & 1.50 \\
\hline 1975 & 106.9 & 193.7 & 1.81 \\
\hline 1976 & 101.3 & 226.7 & 2.24 \\
\hline 1977 & 100.1 & 241.5 & 2.41 \\
\hline 1978 & 97.9 & 222.3 & 2.27 \\
\hline 1979 & 113.4 & 253.6 & 2.24 \\
\hline 1980 & 102.0 & 206.8 & 2.03 \\
\hline 1981 & 122.0 & 252.7 & 2.07 \\
\hline 1982 & 126.4 & 265.6 & 2.10 \\
\hline 1983 & 111.3 & 214.3 & 1.92 \\
\hline 1984 & 93.4 & 193.9 & 2.07 \\
\hline 1985 & 93.3 & 222.7 & 2.39 \\
\hline 1986 & 88.7 & 220.6 & 2.54 \\
\hline 1987 & 85.4 & 174.7 & 2.05 \\
\hline 1988 & 87.7 & 194.6 & 2.22 \\
\hline 1989 & 143.0 & 291.9 & 2.04 \\
\hline 1990 & 107.0 & 205.0 & 1.91 \\
\hline 1991 & 99.4 & 194.1 & 1.95 \\
\hline 1992 & 93.4 & 185.1 & 1.98 \\
\hline 1993 & 90.0 & 176.4 & 1.96 \\
\hline 1994 & 73.2 & 166.1 & 2.27 \\
\hline 1995 & 70.4 & 181.5 & 2.58 \\
\hline 1996 & 74.6 & 179.0 & 2.40 \\
\hline 1997 & 60.6 & 138.4 & 2.28 \\
\hline
\end{tabular}

Notes: PPDI $=$ Index of real producer price of paddy; PCCI $=$ Index of weighted average real producer price of five commercial food crops; (All indices, $1970=100$ ).

RP5CCP $=$ PCCI/PPDI $=$ Ratio of commercial food crop price/paddy price .

Real producer prices $=$ nominal producer prices deflated by GDP deflator for non-plantation agriculture.

Sources: Producer prices of crops, Department of Census and Statistics. Data supplied by the Data Bank, Agrarian Research and Training Institute, Colombo, Sri Lanka. 
Table 2: $\quad$ Land areas cultivated with commercial food crops and agro -industrial crops relative to subsistence food crops, 1970-97

\begin{tabular}{|c|c|c|c|c|c|}
\hline Year & AICC & AIAG & AISB & RA5CS & RAAGS \\
\hline 1970 & 100.0 & 100.0 & 100.0 & 1.00 & 1.00 \\
\hline 1971 & 78.1 & 127.9 & 100.6 & 0.78 & 1.27 \\
\hline 1972 & 94.9 & 96.3 & 76.8 & 1.23 & 1.25 \\
\hline 1973 & 134.3 & 123.4 & 104.8 & 1.28 & 1.18 \\
\hline 1974 & 194.7 & 166.0 & 188.3 & 1.03 & 0.88 \\
\hline 1975 & 194.9 & 178.2 & 164.9 & 1.18 & 1.08 \\
\hline 1976 & 259.1 & 168.7 & 143.8 & 1.80 & 1.17 \\
\hline 1977 & 353.2 & 177.4 & 140.5 & 2.51 & 1.26 \\
\hline 1978 & 318.7 & 149.9 & 113.0 & 2.82 & 1.33 \\
\hline 1979 & 326.2 & 153.8 & 92.8 & 3.51 & 1.66 \\
\hline 1980 & 338.0 & 142.3 & 81.1 & 4.17 & 1.75 \\
\hline 1981 & 432.3 & 160.6 & 101.2 & 4.27 & 1.58 \\
\hline 1982 & 460.3 & 208.6 & 123.8 & 3.71 & 1.68 \\
\hline 1983 & 594.1 & 215.1 & 111.5 & 5.33 & 1.93 \\
\hline 1984 & 533.9 & 200.9 & 115.0 & 4.64 & 1.75 \\
\hline 1985 & 415.6 & 176.5 & 97.2 & 4.28 & 1.81 \\
\hline 1986 & 456.1 & 200.9 & 89.5 & 5.09 & 2.24 \\
\hline 1987 & 530.4 & 212.0 & 83.5 & 6.35 & 2.54 \\
\hline 1988 & 537.5 & 281.9 & 92.6 & 5.80 & 3.04 \\
\hline 1989 & 429.6 & 237.8 & 69.0 & 6.22 & 3.44 \\
\hline 1990 & 603.3 & 259.6 & 95.6 & 6.31 & 2.71 \\
\hline 1991 & 602.8 & 240.6 & 93.3 & 6.46 & 2.58 \\
\hline 1992 & 448.2 & 238.2 & 88.2 & 5.08 & 2.70 \\
\hline 1993 & 442.7 & 261.3 & 92.6 & 4.78 & 2.82 \\
\hline 1994 & 416.7 & 268.8 & 94.4 & 4.41 & 2.85 \\
\hline 1995 & 358.2 & 276.8 & 89.8 & 3.98 & 3.08 \\
\hline 1996 & 361.2 & 276.1 & 78.2 & 4.62 & 3.53 \\
\hline 1997 & 319.7 & 260.0 & 74.0 & 4.32 & 3.51 \\
\hline
\end{tabular}

Notes: AICC $=$ Average index of land area of commercial food crops; AIAG $=$ Average index of land area of agro industrial crops; AISB = Average index of land area of subsistence food crops; (All indices, $1970=100$ ). RA5CS $=$ AICC/AISB $=$ Ratio of commercial food crop area/subsistence food crop area; RAAGS = AIAG/AISB $=$ Ratio of agro-industrial crop area/subsistence food crop area.

Sources: AICC, AIAG, AISB; Compiled using data from Ministry of Agricultural Development and Research (1981) and Central Bank of Sri Lanka (1982; 1987; 1995a;Various Years). 
Table 3: $\quad$ Production of commercial food crops and agro-industrial crops relative to subsistence food crops, 1970-97

\begin{tabular}{rcrrrr}
\hline Year & QICC & QIAG & QISB & RPR5CS & RPRAGS \\
\hline 1970 & 100.0 & 100.0 & 100.0 & 1.00 & 1.00 \\
1971 & 85.4 & 103.4 & 96.8 & 0.88 & 1.07 \\
1972 & 105.0 & 79.3 & 75.5 & 1.39 & 1.05 \\
1973 & 142.5 & 88.3 & 98.3 & 1.45 & 0.89 \\
1974 & 168.3 & 148.5 & 155.5 & 1.08 & 0.95 \\
1975 & 215.3 & 180.8 & 152.8 & 1.41 & 1.18 \\
1976 & 243.5 & 186.8 & 132.2 & 1.84 & 1.41 \\
1977 & 355.8 & 222.1 & 149.1 & 2.38 & 1.49 \\
\hline 1978 & 364.8 & 208.3 & 125.5 & 2.90 & 1.66 \\
1979 & 338.4 & 156.3 & 103.3 & 3.27 & 1.51 \\
1980 & 431.0 & 197.1 & 93.5 & 4.60 & 2.10 \\
1981 & 570.1 & 206.3 & 117.7 & 4.84 & 1.75 \\
1982 & 554.3 & 233.4 & 140.8 & 3.93 & 1.66 \\
1983 & 511.2 & 248.6 & 152.6 & 3.35 & 1.63 \\
1984 & 465.4 & 200.9 & 114.2 & 4.07 & 1.76 \\
1985 & 460.1 & 181.9 & 116.2 & 3.96 & 1.56 \\
1986 & 511.3 & 259.1 & 118.6 & 4.31 & 2.18 \\
1987 & 490.5 & 273.0 & 95.7 & 5.12 & 2.85 \\
1988 & 553.7 & 424.6 & 118.9 & 4.65 & 3.57 \\
1989 & 474.9 & 310.0 & 92.1 & 5.16 & 3.37 \\
\hline 1990 & 603.6 & 414.6 & 88.6 & 6.81 & 4.68 \\
1991 & 564.9 & 366.3 & 96.8 & 5.84 & 3.78 \\
1992 & 632.2 & 304.5 & 90.4 & 6.99 & 3.37 \\
1993 & 681.8 & 347.1 & 101.3 & 6.73 & 3.43 \\
\hline 1994 & 653.6 & 371.3 & 101.8 & 6.42 & 3.65 \\
1995 & 588.5 & 337.3 & 98.6 & 5.97 & 3.42 \\
1996 & 573.4 & 361.5 & 78.7 & 7.28 & 4.59 \\
1997 & 518.6 & 320.1 & 79.4 & 6.53 & 4.03 \\
\hline
\end{tabular}

Notes: $\mathrm{QICC}=$ Average index of production of commercial food crops; $\mathrm{QIAG}=$ Average index of production of agro industrial crops; QISB = Average index of production of subsistence food crops; (All indices, $1970=100)$. RPR5CS = QICC/QISB = Ratio of commercial food crop production/subsistence food crop production; RPRAGS

$=$ QIAG/QISB $=$ Ratio of agro-industrial crop production/subsistence food crop production.

Sources: QICC, QIAG, QISB; Compiled using data from Ministry of Agricultural Development and Research (1981) and Central Bank of Sri Lanka (1982; 1987; 1995a;Various Years). 
Table 4: $\quad$ Yields of commercial food crops and agro-industrial crops relative to subsistence food crops, 1970-97

\begin{tabular}{crrrrr}
\hline YEAR & YICC & YIAG & YISB & RY5CS & RYAGS \\
\hline 1970 & 100.0 & 100.0 & 100.0 & 1.00 & 1.00 \\
1971 & 109.2 & 81.6 & 96.3 & 1.13 & 0.85 \\
1972 & 121.6 & 83.1 & 106.2 & 1.14 & 0.78 \\
1973 & 108.7 & 72.1 & 93.9 & 1.16 & 0.77 \\
1974 & 113.0 & 97.1 & 86.1 & 1.31 & 1.12 \\
1975 & 138.3 & 101.0 & 95.9 & 1.44 & 1.05 \\
1976 & 118.0 & 110.4 & 97.7 & 1.21 & 1.13 \\
1977 & 121.0 & 123.2 & 110.1 & 1.10 & 1.12 \\
\hline 1978 & 153.2 & 138.2 & 114.2 & 1.34 & 1.21 \\
1979 & 156.5 & 105.0 & 121.7 & 1.28 & 0.86 \\
1980 & 165.8 & 139.8 & 119.8 & 1.38 & 1.17 \\
1981 & 166.1 & 128.4 & 121.9 & 1.36 & 1.05 \\
1982 & 160.0 & 110.0 & 119.7 & 1.34 & 0.92 \\
1983 & 146.0 & 111.1 & 134.1 & 1.09 & 0.83 \\
1984 & 117.6 & 99.0 & 95.8 & 1.23 & 1.03 \\
1985 & 156.3 & 102.2 & 116.7 & 1.34 & 0.88 \\
1986 & 156.0 & 128.8 & 127.2 & 1.23 & 1.01 \\
1987 & 153.5 & 128.3 & 113.9 & 1.35 & 1.12 \\
1988 & 162.2 & 150.3 & 126.9 & 1.28 & 1.18 \\
1989 & 162.5 & 129.0 & 130.0 & 1.25 & 0.99 \\
\hline 1990 & 143.8 & 159.8 & 98.8 & 1.45 & 1.61 \\
1991 & 139.1 & 151.9 & 109.0 & 1.27 & 1.39 \\
1992 & 219.2 & 126.6 & 102.6 & 2.13 & 1.23 \\
1993 & 232.4 & 129.9 & 110.8 & 2.10 & 1.17 \\
\hline 1994 & 223.0 & 133.3 & 110.8 & 2.01 & 1.20 \\
1995 & 236.1 & 120.2 & 108.9 & 2.17 & 1.10 \\
1996 & 240.8 & 129.0 & 102.7 & 2.34 & 1.25 \\
1997 & 252.1 & 122.0 & 107.0 & 2.35 & 1.14 \\
\hline
\end{tabular}

Notes: YICC $=$ Average index of yields of commercial food crops; YIAG $=$ Average index of yields of agro industrial crops; YISB = Average index of yields of subsistence food crops; (All indices, $1970=100)$. RY5CS $=$ YICC/YISB = Ratio of commercial food crop yield/subsistence food crop yield; RYAGS = YIAG/YISB = Ratio of agro-industrial crop yield/subsistence food crop yield.

Sources: YICC, YIAG, YISB; Compiled using data from Ministry of Agricultural Development and Research (1981) and Central Bank of Sri Lanka (1982; 1987; 1995a; Various Years). 
between agro-industrial crops and subsistence food crops (Table 4$)^{11}$.

All these ratios indicate that crop diversification and commercialisation of non-plantation agriculture occurred much faster during 1978-97 than during 1970-77. It is evident that during 1978-97, land areas cultivated with both commercial food crops and agro-industrial crops have increased faster than subsistence food crops. However, there has been a declining trend in areas cultivated with the five commercial food crops and paddy during 1994-97 compared to all previous periods (Table 2). The ratios in table 3 indicate that the production of commercial food crops and agroindustrial crops tended to increase much faster than the subsistence food crops during much of 1978-97, with downward swings of ratios during 1981-83 ${ }^{12}$. However, the production of commercial food crops and subsistence food crops shows a clear downward trend during 1994-97. The ratios of yield indices in table 4 show large swings during the period under study. During 1978-89, yields of commercial food crops and agroindustrial crops do not appear to have increased faster than subsistence crops, but during 1991-97 the reverse situation is observed.

\section{Outward Orientation of Non- Plantation Agriculture}

The trends in imports of importcompeting products and the trends in exports are examined in this section as indicators of outward orientation of non-plantation agriculture, especially, during 1978-97.

\section{Imports of Import-competing Products}

During much of 1978-97 the nonplantation agricultural sector was protected from import competition, within a broad framework of economic liberalisation. This was for reasons of 'food security' and political and social considerations, as the largest proportion of population live in rural areas and a large proportion of this population earn their livelihood from food crops either as farmers or labourers. Data on the real value of imports of four major importcompeting products (rice, red and big onions, potatoes and chillies), produced in the non-plantation agricultural sector are presented in

11. This analysis is confined to relative area, output and yield relations between different categories of crops. Others have looked at the trends in the absolute values of area, output and yield in relation to individual crops (see, for example, Dunham).

12. The data for production and yield are less reliable than area data. Moreover, weather fluctuations affect production and hence yield, irrespective of other factors. However, we found a positive, but low correlation between production indices and annual rainfall index in relation to paddy $(\mathrm{r}=0.28)$ and the five commercial crops $(\mathrm{r}=0.22)$. 
table 5. These products were mainly imported by government agencies (Food Commissioner's Department and the Co-operative Wholesale Establishment) or by private firms subject to tariffs/quotas (with licenses). Thus, imports were either a government monopoly or regulated by the government.

Imports of rice were never prohibited totally. In fact during the pre-reform period (1970-77), the real value of rice imports was much higher than that during 1978-97. However, real value of rice imports declined sharply during 1978-95 owing to rapid increases in domestic rice production and dismantling of the public rice distribution system. During 1973-77, imports of chillies and onions were almost totally prohibited, while imports of potatoes were severely curtailed. With the initial trade liberalisation measures during 1978-82, large quantities of onions were imported, having an adverse impact on production in the major producing areas in the north and east of the country (Gunasinghe, 1986).

When production was disrupted due to civil wars in these areas from 1983 , production accelerated in other areas of the country, but after 1982 real value of imports (especially of big onions) have generally increased. Real value of imports of potatoes surged during 1978- 79, but declined rapidly thereafter until 1993 . There are no recorded imports of potatoes during 1985-93, except for 1989. Real imports of chillies increased rapidly during 1978-79, but thereafter the general trend in imports of chillies is also a downward one, with wide fluctuations, which correspond to domestic production trends.

Thus, evidence suggests that during 1978-93, imports of importcompeting products (except rice) of non-plantation agriculture have increased initially for 2-3 years after economic reforms, and thereafter tended to decline as protection was given to domestic produces to alleviate adverse political and social repercussions of trade liberalisation. However, during 1994-97, imports of rice, potatoes, onions and chillies generally increased (Table 5) following the relaxation of import restrictions on these food items and the permission granted for the private sector to import such items. 
Table 5: $\quad$ Real value of imports of selected food items, 1970-97 (Rs. Million)

\begin{tabular}{|c|c|c|c|c|}
\hline Year & Rice & Potatoes & Onions & Chillies \\
\hline 1970 & 1765.6 & 1.1 & 161.7 & 147.2 \\
\hline 1971 & 1026.8 & 20.0 & 4.2 & 158.9 \\
\hline 1972 & 730.9 & 34.5 & 0.1 & 110.9 \\
\hline 1973 & 965.0 & 6.4 & 0.0 & 0.0 \\
\hline 1974 & 1385.6 & 10.6 & 0.1 & 0.0 \\
\hline 1975 & 1609.2 & 1.7 & 0.1 & 0.0 \\
\hline 1976 & 1337.1 & 4.4 & 0.0 & 0.0 \\
\hline 1977 & 1636.6 & 1.1 & 0.0 & 0.0 \\
\hline 1978 & 689.4 & 9.2 & 0.3 & 30.1 \\
\hline 1979 & 775.4 & 30.7 & 25.7 & 93.9 \\
\hline 1980 & 427.2 & 6.8 & 46.4 & 98.9 \\
\hline 1981 & 349.7 & 1.0 & 6.0 & 3.6 \\
\hline 1982 & 259.2 & 0.0 & 16.3 & 25.6 \\
\hline 1983 & 399.0 & 2.5 & 21.1 & 71.0 \\
\hline 1984 & 63.6 & 0.7 & 124.3 & 98.3 \\
\hline 1985 & 357.6 & 0.0 & 137.2 & 45.3 \\
\hline 1986 & 357.4 & 0.0 & 118.8 & 35.8 \\
\hline 1987 & 151.4 & 0.0 & 93.8 & 26.8 \\
\hline 1988 & 441.3 & 0.0 & 22.8 & 80.6 \\
\hline 1989 & 300.7 & 1.2 & 9.4 & 15.0 \\
\hline 1990 & 199.3 & 0.0 & 43.5 & 23.2 \\
\hline 1991 & 235.4 & 0.0 & 92.8 & 71.6 \\
\hline 1992 & 376.7 & 0.0 & 46.7 & 63.7 \\
\hline 1993 & 310.4 & 0.0 & 52.2 & 7.0 \\
\hline 1994 & 83.3 & 11.4 & 72.9 & 38.0 \\
\hline 1995 & 13.3 & 17.7 & 95.7 & 52.0 \\
\hline 1996 & 500.4 & 40.8 & 114.9 & 63.0 \\
\hline 1997 & 413.6 & 124.4 & 131.3 & 56.2 \\
\hline
\end{tabular}

Note: Real value of imports = c.i.f. import value deflated by the Import Price Index (Consumer good imports). $1978=100$.

Sources: C.i.f. value of imports, Department of Customs, Data supplied by the Data Bank, Agrarian research and Training Institute, Colombo, Sri Lanka, Import Price Index, 1970-89, Athukorala and Jayasuriya (1994); 1990-93, Central Bank of Sri Lanka (1995a; Various Years). 


\section{Exports}

Exports of products from nonplantation agriculture were negligible during 1970-77, except for small quantities of vegetables, chillies and fruits exported to the neighbouring countries of the Indian sub-continent. However, with the export incentives provided under the liberalised trade regime during 1978-97, there has been a rapid increase in the exports of vegetables, chillies, cut flowers and fruits.

Major vegetable exports include new products such as green chillies, gherkins, capsicum, mushrooms, leeks and potatoes. The Maldive Islands and the Middle East are the major export markets. Major fruit exports include pineapple, mango, and citrus fruit ${ }^{13}$. As an example of export growth of products from nonplantation agriculture, the data on real values of exports of vegetables (fresh, chilled, dried and preserved) are presented in table 6 . The real value of exports increased rapidly during 197889 , but tended to fall slightly during 1990-97.

\section{Current Issues and Prospects for Non-Plantation Agriculture}

The current problems in the nonplantation agricultural economy of Sri Lanka are summarised by the National
Development Council (1996) as low and stagnant yields, declining output, low intensity of use of irrigated lands, low farm family income and employment; sharp increases in prices of inputs; and prices of products not keeping pace with the rising costs of production. Our analysis in this paper shows that during 1994-97, area cultivated, total production and yield of almost all crops generally declined, compared to previous periods (see Tables 2, 3, and 4). The annual average factor cost GDP deflator for non-plantation agriculture $(1970=100)$ increased from 1203.4 during 1990-93 to $\quad 1859.1 \quad$ during 1994-97 (Gunawardana and Somaratne, 1999). This shows the extent of inflation of input prices. The declining trend in real producer prices during 1994-97 as shown in table 1 is an indicator of prices of products not keeping pace with the rising costs of production. Although fertiliser use and tractor availability improved slightly during 1994-97 compared to 1990-93, irrigation investments declined slightly while institutional credit provision declined sharply during 1994-97 (Gunawardana and Somaratne, 1999).

From the above facts it is clear that both factor and product markets catering to the non-plantation agriculture are not functioning

13. See for details, Dunham (1992; 1993). 
properly. This is partly a result of historically high degree of government intervention, which resulted in inefficiencies. Gradual reduction in government intervention in agricultural factor and product markets since 1978 has improved the situation considerably. Further encouragement of private sector participation and competition will remove remaining imperfections and rigidities in markets for agricultural products.

However, the absence or malfunctioning of factor input markets act as stumbling blocks against economic performance of nonplantation agriculture. In particular, development of properly functioning land and water (irrigated) markets with private property rights needs attention in policy circles. Private property rights and freely transferable lands will ensure that marginal farmers operating uneconomic minute land holdings relinquish farming and are employed in off-farm activities, while commercially viable farmers consolidate their land holdings. Private property rights in irrigation water and charging of water rates from farmers will prevent waste and mismanagement of water, and also enable recovery of at least operation and maintenance costs. Demand for institutional credit in the rural sector is limited at present, mainly as a result of historically high degree of farmers' opting for 'self-financing', and procedural and bureaucratic rigidities with regard to institutional credit compared to convenience in obtaining credit from private sources. Encouraging competition among agricultural financing institutions and improving and service standards among the financial institutions and private sources is the key to improve the rural credit market.

The National Policy Framework (NPF) prepared by the Ministry of Agriculture and Lands in 1995 (cited in Central Bank of Sri Lanka, 1998) focuses on the following priority areas to improve the economic performance of non-plantation agriculture: (a) provision of high quality seed and planting materials; (b) streamlining the agricultural extension services; and (c) assisting an integrated approach by the private sector and non-governmental organisations in developing the agricultural sector, with the government providing a supportive role to achieve the policy objectives. However, the NPF has not focused on a long-term vision for the non-plantation agriculture in considering the future changes in policy environments such as 'globalisation' and regional trading arrangements. 
Table 6: $\quad$ Real value of exports of vegetables, 1970-97 (Rs. Million)

\begin{tabular}{|c|c|}
\hline Year & Real Value of Exports of Vegetables \\
\hline 1970 & 0.06 \\
\hline 1971 & 0.00 \\
\hline 1972 & 0.07 \\
\hline 1973 & 0.00 \\
\hline 1974 & 0.48 \\
\hline 1975 & 0.48 \\
\hline 1976 & 0.41 \\
\hline 1977 & 2.31 \\
\hline 1978 & 8.20 \\
\hline 1979 & 9.13 \\
\hline 1980 & 10.04 \\
\hline 1981 & 20.83 \\
\hline 1982 & 23.00 \\
\hline 1983 & 30.37 \\
\hline 1984 & 29.69 \\
\hline 1985 & 23.83 \\
\hline 1986 & 34.30 \\
\hline 1987 & 32.31 \\
\hline 1988 & 37.48 \\
\hline 1989 & 42.51 \\
\hline 1990 & 30.55 \\
\hline 1991 & 14.79 \\
\hline 1992 & 30.17 \\
\hline 1993 & 34.42 \\
\hline 1994 & 31.88 \\
\hline 1995 & 12.82 \\
\hline 1996 & 37.39 \\
\hline 1997 & 16.45 \\
\hline
\end{tabular}

Note: Real value of exports = f.o.b. export value deflated by the Export Price Index (All exports), $1978=100$.

Source: f.o.b. value of exports, Department of Customs, Data supplied by the Data Bank, Agrarian Research and Training Institute, Colombo, Sri Lanka. Export Price Index, 1970-89, Athukorala and Jayasuriya (1994); 1990-97, Central Bank of Sri Lanka (1995a; Various Years). 
Economic policy liberalisation under structural adjustment policies, along with GATT/Uruguay Round Agreement on Agriculture (GURAA), have opened new horizons and policy directions for developing countries. Agricultural input and output markets and policies are to be liberalised further, allowing the private sector to play a greater role as an 'engine of economic growth'. In Sri Lanka, the nonplantation agricultural sector has to exist within the new liberalised world economic policy environment to enhance economic growth. As explained in Athukorala and Kelegama (1996), the effect of GURAA on the world market prices of rice, sugar, milk powder and other milk products, has been estimated to be virtually zero. In the Sri Lankan context, the most significant feature is the effect of an increase in the price of wheat and wheat flour, due to the removal of agricultural production subsidies in major producing (developed) countries.

Under the South Asian Preferential Trading Arrangement $(\text { SAPTA })^{14}$, there is a possibility for Sri Lanka to take advantage of imports of chillies, onions, and potatoes from India and Pakistan. These crops are currently produced in the nonplantation agricultural sector with high social cost to the economy of Sri Lanka (Somaratne, 1998). Thus, priorities should be placed on increasing domestic production of other import-competing products such as paddy/rice, sugar, maize, cowpea, and green gram.

While border protection for import-competing food crops is being reduced, there is scope for implementing production incentives by way of complementary domestic policies. These policies include input subsidies, infrastructure development, research and development subsidies which are allowed for developing countries under the GATT/Uruguay Round Agreement on Agriculture. Exportable surplus of export crops such as vegetables and fruits can also be increased through these same policies.

Horizontal crop diversification (changing the crop mix away from paddy and other subsistence crops towards commercial crops) may be encouraged, but it is also important to realise that there is a limit to this strategy. With farmers opting for offfarm work at higher wages during lean seasons of paddy cultivation, rather than growing high-value and high-risk commercial crops, it would be unrealistic to expect any greater shifts of land and other resources from

14. See, for details, Central Bank of Sri Lanka (1995b, pp. 110-11). 
subsistence to commercial crops. Therefore, possibilities for vertical diversification can be explored as a supplement, or in some cases as an alternative, to horizontal diversification. Vertical diversification in this context means the development of food crop based agro-processing (value adding) industries of the kind that already exist for flour making and food preparation (for example, noodles) from rice, kurakkan and green gram for domestic and export markets so that 'over production' of such crops will not be a 'problem'. For these purposes, private sector should be encouraged to infuse new technology and other necessary investment with a sector-specific comprehensive package of incentives.

Despite more than three decades of the 'green revolution', food crop production technology in Sri Lanka is such that yield per unit of land of most food crops (except perhaps rice) are below the achievements in some other countries in the south and south-east Asian region. Thus, yield-increasing technology should receive priority in the new agricultural development strategy. However technological change in agriculture will not be automatic under economic liberalisation. Moreover, public good characteristics of research dictates that the private sector under-invests in research, and there is always an important role for the government in agricultural research and development. In this regard, direct government intervention may be a necessity in a developing country such as Sri Lanka, where food crop production is mainly carried out by a large number of dispersed farmers working on very small land holdings. It is doubtful whether even research and development subsidies will entice the private sector to undertake all research and development activities in such an economically risky environment.

\section{Concluding Remarks}

This paper provided an overview of policies toward non-plantation agriculture in Sri Lanka from 1970 to date, examined the diversification, commercialisation and outward orientation of non-plantation agriculture during 1970-97, and outlined the current issues and prospects for non-plantation agriculture. The major conclusions drawn from the analysis are summarised below.

The commercial food crop/paddy price ratio demonstrates a general downward trend during 1978-93 suggesting that real prices of commercial food crops did not increase faster than the real prices of subsistence food crops. However, during 1994-97, the commercial food crop/paddy price ratio shows a general upward 
trend compared to the period 197893.

During 1978-91, the land areas cultivated with, and the production of commercial food crops have increased much faster than subsistence food crops. However, during 1992-97 there is a declining trend in the land area of commercial food crops relative to subsistence food crops, although production of commercial food crops shows an increasing trend relative to subsistence food crops. The land area and production of agro-industrial crops relative to subsistence food crops have increased throughout 197897. During 1978-97, yields of agroindustrial crops do not appear to have increased faster than subsistence food crops. The yields of commercial food crops also do not appear to have increased faster than the yields of subsistence food crops during 197891, but during 1992-97 the yields of commercial food crops increased much faster than the yields of subsistence food crops.

Real value of imports of rice declined sharply during 1978-93 owing to rapid increases in domestic rice production. With initial trade liberalisation measures, large quantities of onions were imported during 1978-80, with adverse repercussions on domestic production. After 1982 the real imports (especially of big onions) have generally increased. The imports of potatoes surged during 1978-79, but declined thereafter. During 1978-79, imports of chillies increased rapidly, but since then generally declined. Thus, evidence suggests that imports of import-competing products (except rice) of non-plantation agriculture have increased initially for 2-3 years after economic reforms, and then tended to decline as protection given to domestic producers to alleviate adverse political and social repercussions are gradually removed. However, again during 1994-97, imports of rice, potatoes, onions and chillies generally increased as a result of relaxation of import restrictions.

With the export incentives given under economic reforms, there has been a rapid increase in real exports of some products from non-plantation agriculture, such as vegetables, chillies, cut flowers and fruits, especially during 1978-93.

During 1994-97, area cultivated, total production and yield of almost all crops generally declined, compared to previous periods. There has been a sharp escalation of inflation of input prices. The declining trend in real producer prices indicates that prices of products do not keep pace with the rising costs of production. Fertiliser use and tractor availability improved slightly, irrigation investments declined slightly while institutional 
credit provision declined sharply.

Gradual reduction in government intervention since 1978 has improved agricultural factor and product markets considerably. Further encouragement of private sector participation and competition will remove remaining imperfections and rigidity in markets for agricultural products.

The malfunctioning of factor input markets creates negative economic performance in nonplantation agriculture. It is advisable to facilitate through policy environment to develop properly functioning land and irrigation-water markets along with securing private property for maintaining efficiency in the input factor markets. Encouraging competition in relation to interest rates and service standards among the financial institutions and private sources is the key to improve the rural credit market.

The National Policy Framework has not focused on a long-term vision for tradable non-plantation agriculture in considering the future changes in policy environments such as 'globalisation' and 'regionalisation'.

Sri Lanka can import chillies, onions, and potatoes cheaply from India and Pakistan under the South Asian Preferential
Arrangement (SAPTA), rather than producing total requirement of these crops domestically with higher social costs. Therefore, priorities should be placed on increasing domestic production of other import-competing products such as paddy/rice, sugar, maize, cowpea, and green gram. There is scope for implementing production incentives for these crops by way of complementary domestic policies. These policies include input subsidies, infrastructure development, research and development subsidies which are allowed for developing countries under the GATT/Uruguay Round Agreement on Agriculture. Exportable surpluses of export crops such as vegetables and fruits can also be increased through these same policies.

Possibilities for further development of food crop based agroprocessing (value adding) industries should be considered to expand employment opportunities for rural labour. For these purposes, private sector should be encouraged to infuse new technology and other necessary investment with a sector-specific comprehensive package of incentives.

As scope for further expansion of cultivable land area is limited, yieldincreasing technology should receive priority in the new agricultural development strategy. Public good characteristics of research dictate that the private sector under-invests in 
research, and therefore the government should play an active role in promoting and providing agricultural research, development and extension services.

\section{Acknowledgment}

The authors wish to thank M.A. Gunawardana and staff of the Data Bank of Hector Kobbekaduwa Agrarian Research and Training Institute, Colombo for providing some of the data used in this paper. Usual caveat applies. Parts of this paper are also included in Gunawardana and Somaratne (1999).

\section{References}

Athukorala, P. and S. Jayasuriya (1994). Macroeconomic Policies, Crises and Growth in Sri Lanka, 1969-90. The World Bank, Washington, D.C.

Athukorala, P. and S. Kelegama (1996). Agricultural Trade Liberalisation in the Uruguay Round: Implications for Sri Lankan Agriculture. Paper Presented at the World Bank/FAO, South Asia WTO Seminar, Kathmandu, Nepal.

Bandara, J.S. and P.J. Gunawardana (1989). Trade Policy Regimes and Structural Changes: The
Case of Sri Lanka. Discussion Paper No. 6/89, School of Economics, la Trobe University, Bundoora, Victoria, Australia.

Bhalla, S. (1991). Sri Lanka. In, A. Krueger, M. Schiff and A. Valdes (eds.), The Political Economy of Agricultural Pricing Policy, Vol. 2, Asia, Baltimore: Johns Hopkins University Press (for the World Bank).

Central Bank of Sri Lanka (1982). Economic and Social Statistics of Sri Lanka. Vol. V, Central Bank of Sri Lanka, Colombo, Sri Lanka.

Central Bank of Sri Lanka (1987). Economic and Social Statistics of Sri Lanka. Vol. $\mathrm{X}$, Central Bank of Sri Lanka, Colombo, Sri Lanka.

Central Bank of Sri Lanka (1995a). Economic and Social Statistics of Sri Lanka. Central Bank of Sri Lanka, Colombo, Sri Lanka.

Central Bank of Sri Lanka (1995b). Annual Report. Central Bank of Sri Lanka, Colombo, Sri Lanka. 
Central Bank of Sri Lanka (1997a). Annual Report. Central Bank of Sri Lanka, Colombo, Sri Lanka.

Central Bank of Sri Lanka (1998). Annual Report. Central Bank of Sri Lanka, Colombo, Sri Lanka.

Central Bank of Sri Lanka (Various Years). Annual Report. Central Bank of Sri Lanka, Colombo, Sri Lanka.

Centre for International Economics (1995). Ministry of Industrial Development, Industry Sector Policy Review, Sri Lanka, TA No. 2161-SRI, Centre for International Economics, Canberra.

Cuthbertson, S. and P. Athukorala (1991). Sri Lanka. In, A.M. Choksi and D. Papageorgiou (eds.), Economic Liberalisation in Developing Countries, Oxford: Blackwell.

Dunham, D. (1992). Increased Productivity and Commercialisation of NonEstate Agriculture. Research Studies, Agricultural Policy Series No. 2, Institute of Policy Studies, Colombo, Sri Lanka.
Dunham D. and S. Kelagama. (1994).

The Second Wave of Liberalisation in Sri Lanka 1989-93: Reform and Governance. Paper Presented at the International Conference on Economic Liberalisation of South Asia, Australian National University, Canberra.

Edirisinghe, N. (1987). The Food Stamp Scheme in Sri Lanka: Costs, Benefits and Options for Modification. Research Report No. 58, International Food Policy Research Institute, Washington, D.C.

Edirisinghe, N. and T.T. Poleman (1976). Implications of Government Intervention in the Rice Economy of Sri Lanka. Cornell International Agriculture Mimeograph No. 48, Cornell University, Ithaca.

Edwards, C. (1993). A Report on Protectionism and Trade Policy in Manufacturing and

Agriculture in Sri Lanka. Institute of Policy Studies, Colombo, Sri Lanka.

Gavan, J.D. and I.S. Chandrasekera (1979). The Impact of Public Food Grain Distribution on Food Consumption and 
Welfare in Sri Lanka. Research Report 13, International Food Policy Research Institute, Washington, D.C.

Gunasinghe, N. (1986). Open Economic Policy and Peasant Production. Upanathi: Journal of Sri Lanka Association of Economists, 1: 37-68.

Gunawardana, P.J. (1981a). Land Policy and Agrarian Change in Independent Sri Lanka. Sri Lanka Journal of Agrarian Studies, 2: 27-43.

Gunawardana, P.J. (1981b). Agricultural Credit Schemes under the Kurunegala Rural Development Project: An Evaluation. Research Study No. 49, ARTI, Colombo, Sri Lanka.

Gunawardana, P.J. (1983). Ongoing Evaluation of Rural Development Projects: Experience from Sri Lanka. In, C. Barlow and H.V. Richter (eds.), Data Requirements for Rural Development Planning. Papers from a Conference held in Kuala Lumpur, 1981, Development Studies Centre, Australian National
University, Canberra, pp. 147-160.

Gunawardana, P.J. (1987). Rice Pricing and Marketing Policies in Sri Lanka, 195284: A Welfare Evaluation. Unpublished Ph.D. Thesis, La Trobe University, Bundoora, Victoria, Australia.

Gunawardana, P.J. (1997). Concessional Sales, Open Market Demand and Consumption of Rice in Sri Lanka, 1953-1989. Paper Presented to the $41^{\text {st }}$ Annual Conference of the Australian Agricultural and Resource Economics Society, Gold Coast, Queensland, Australia.

Gunawardana, P.J. and J.J. Quilkey (1987). Pricing and Marketing Policies in the Rice Sector of Sri Lanka: History and Impact. Upanathi: Journal of Sri Lanka Association of Economists, 1: 227-279.

Gunawardana, P.J. and J.J. Quilkey (1993). Determinants of Paddy Sales on the Official Market in Sri Lanka, 19531989. Indian Journal of Agricultural Economics, XLVIII: 649-657. 
Gunawardana, P.J. and W.G. Somaratne (1999). Economic Policy Regimes and NonPlantation Agriculture in Sri Lanka Since 1970. Chapter 11. In, W.D. Lakshman and C.A. Tisdell (eds.), Facets of Development of Sri Lanka Since Independence: SocioPolitical, Economics, Scientific and Cultural. Conference Monograph No. 6, Department of Economics, University of Queensland, Brisbane, pp. 257-285.

Lakshman, W.D. (1994). Structural Adjustment Policies in Sri Lanka: Imbalances, Structural Disarticulation and Sustainability. Paper Presented to the International Conference on Economic Liberalisation of South Asia, Australian National University, Canberra.

Ministry of Agricultural Development and Research (1981). Agricultural Statistics of Sri Lanka, 1951-52/1980-81. Associated Newspapers Limited, Colombo, Sri Lanka.

National Development Council (1996). Report of the Working Group on Agricultural Policy. Vol. 1, Colombo, Sri Lanka.
National Planning Division (1984). National Agriculture, Food and Nutrition Strategy: A Change in Perspective. Ministry of Finance and Planning, Colombo, Sri Lanka.

Presidential Commission on Tariffs and Trade (PCTT) (1994). Report of the Presidential Commission on Tariffs and Trade. Colombo, Sri Lanka.

Rajapathirana, S. (1988). Foreign Trade and Economic Development: The Case of Sri Lanka. World Development, 16: 1143-1157.

Richards, P.J. and W. Gooneratne (1980). Basic Needs, Poverty and Government Policies in Sri Lanka. ILO, Geneva.

Sirisena, N.L. (1986). An Evaluation of Agricultural Policy on the Paddy Sector, 1950-1985. Sri Lanka Economic Journal, 1: 66-97.

Somaratne, W.G. (1998). Policy Reforms and the Environment: A General Equilibrium Analysis of Land Degradation in Sri Lanka. Unpublished Ph.D. Thesis, School of Business, 
La Trobe University, World Bank (1990). Sri Lanka Sector Bundoora, Victoria, Australia. Study and Programming Mission. Final Report, The

Thorbecke, E. and J. Svejnar (1987).

Economic Policies and World Bank, Washington,

Agricultural Performance in

Sri Lanka, 1960-1984. OECD, Paris.

D.C.

World Trade Organization (WTO) (1995). Trade Policy Review Body - Sri Lanka. Report by

Wickremeratne, L.A. (1977). Peasant the Secretariat -Summary and Agriculture. In, K.M. De Observations, World Trade Silva (ed.), Sri Lanka: A Survey, London: C. Hurst \& Organization, Geneva.

Co. 